\title{
Introduction \\ Textbooks in Periods of Political Transition after the Second World War
}

\author{
Kira Mahamud Angulo and Anna Ascenzi
}

\section{Textbooks and Political Transition}

This special issue examines textbooks in countries undergoing political transition, change, and convulsion. The articles consider textbooks from countries shifting from one political regime to another, "at different speeds and with different priorities, ${ }^{11}$ in the second half of the twentieth century. The articles raise a number of questions. What happens to textbooks during the intervals between one form of government and another? How does the information contained in textbooks change during these intervals of instability and uncertainty, and during the phases of the construction and consolidation of a new political regime?

Contributors to this issue examine textbooks from four countries that are struggling to leave authoritarian regimes behind while endeavoring to build and consolidate democratic systems and societies. In their recent study of education in Central Asia, Pinar Akçali and Cennet Engin-Demir state that the curriculum challenges facing all societies in transition (including Kyrgyzstan) fall into three categories: "the challenge of pedagogy, the challenge of introducing the new subject matter and the challenge of teaching civics, social studies and history." ${ }^{2}$ In keeping with this notion, we present in this volume a variety of textual genres with a focus on their didactical characteristics or on the teaching of particular topics, and an exposition of how these and other challenges are met. We thereby attempt to throw light on the impact of political transition on textbooks, and to interpret the roles assigned to educational texts in this particular context.

\section{The Origin of this Special Issue}

The MANES Research Center of the Spanish National University of Distance Education (Universidad Nacional de Educación a Distancia, UNED) (Madrid, Spain) and the Center for Documentation and Research on the History of Schoolbooks and Children's Literature (Centro di 
documentazione e ricerca sulla storia del libro scolastico e della letteratura per l'infanzia, CESCO) of the University of Macerata (Italy) organized an international symposium titled "Education in Periods of Political Transition," which took place at the International Center of School Culture (Centro Internacional de la Cultura Escolar, CEINCE) in Berlanga de Duero (Soria, Spain) from 13 to 15 April 2015. The symposium addressed two main themes of education in times of transition between dictatorship and democratic society: political socialization and civic education. Scholars from Germany, Italy, Portugal, and Spain ${ }^{3}$ presented and discussed ${ }^{4}$ national case studies, two of which (Paolo Bianchini and Maria Cristina Morandini's examination of civic education in Italy and Kira Mahamud and Yovana Hernandez's analysis of economic knowledge in textbooks), appear in this issue.

As Anna Ascenzi, one of the organizers of the symposium, explained in her opening remarks, the in-depth investigation of a topic such as education in periods of political transition necessarily implies a reflection on the special role that education has played historically in the civil and political evolution of countries, thanks to its extraordinary potential to further (among other things) the construction of national identity and the promotion of democratic citizenship, but also because of the historical tendency, especially evidenced by the totalitarian regimes of the twentieth century, of governments to instrumentalize it for ideological and political purposes. Many of the participants responded to the challenge of analyzing the role of education in tumultuous political contexts by grounding their studies in the historiographical materials that best demonstrate the knowledge actually being conveyed to schoolchildren in a given historical moment.

By moving away from the focus on southern Europe and offering a wider vision of the evolution of certain topics in the textbooks of countries belonging to what Samuel Huntington has called the "third wave transitions to democracy"5 after the Second World War, this volume combines contributions from the symposium with other papers that extend the study of the topic to other countries. In these articles, researchers from Albania, Indonesia, Italy, and Spain analyze the transformation that textbook information underwent during the dismantling of regimes or governments in their respective countries during their transition to a democratic political system, and during the early days of their nascent democracies that were marked by the construction or consolidation of democracy.

In these analyses, we encounter an inevitable methodological convergence since no area of research is isolated, and because the authors conduct their studies within a broader historical context. The selection of textbooks followed certain fixed criteria, outweighing the repute or 
relevance of the author and the prestige or relevance of the publisher. In their analyses, the authors give precedence to texts over images, and employ both content and discourse analysis.

\section{Transition as a Dynamic Process}

We prefer to use the phrase "transition to a democratic regime" rather than the term "democratic transition," since these processes were not always themselves "democratic." However, we adhere to the definition of the phenomenon as set forth by Enrique Baloyra in 1987, following the consolidation of the southern European democracies, as

(1) a process of political change (2) initiated by the deterioration of an authoritarian regime, (3) involving intense political conflict (4) among actors competing (5) to implement policies grounded on different (even mutually exclusive) conceptions of the government, the regime, and the state ... [and which is] (6) resolved by the breakdown of that regime leading to (7) the installation of a government committed to the inauguration of a democratic regime and/or (8) the installation of a popularly elected government committed to the inauguration of a democratic regime. ${ }^{6}$

Baloyra's inclusion of the phases of transition and the conflicts between competing actors in his definition indicates the complexity of the process. The analyses presented in this volume are not limited to the actual years of political transition and regime or governmental change. This is because, as we shall see, in the process of transition the economic, social, educational, and political spheres of society often become desynchronized. A similar approach to this process is provided in Daniel Ziblatt's description of nineteenth century democratization as "an asynchronic dynamic in which the different dimensions of democracy (universal suffrage, parliamentary autonomy, civil rights) were created at different time possibly for different reasons, ${ }^{77}$ and the focus on democratization in terms of the creation and reconfiguration of democratic institutions. ${ }^{8}$ Although each country has its own idiosyncrasies, it is possible to draw parallels and to find both analogies and differences in the "closing phases of authoritarian rule," "democratic openings" and "consolidations" examined, as well as in the textbooks produced during such complex processes. Furthermore, adhering to the historical turn in democratization studies, it is possible to address education as one of the agents of the process, a non-class factor driving institutional change, ${ }^{10}$ focusing on a key politico-educational mechanism of one of its institutions, the school, and demonstrating how the dynamic and unstable process of political transition affects textbooks. 


\section{Democratization Processes}

Three of the four countries examined in this volume (Albania is the exception) had experienced democratic systems in the past, and thus may be approached, following Juan José Linz's theory, as cases of redemocratization, a process involving an "experiment with the operation of democratic institutions" and "a collective memory of the difficulties previously encountered by those institutions, which led them to crisis and collapse." ${ }^{11}$ Given that each democratization process is unique, each textbook should be viewed in the context of that particular country's transition towards democratic development. ${ }^{12}$

\section{Triggering Factors}

In addition to this redemocratization process, we must also consider, in the case of each country, the starting point from which the transition began and the particular characteristics of the process-the factors that shape the process and its outcome, and which may lead to various types of democracy ${ }^{13}$ or ongoing democratization processes, all of which leave traces in textbooks.

Whereas Spain and Indonesia broke with their longstanding dictatorial systems, in Italy the transition was more gradual, and was rooted, first, in the collapse of the fascist system at the end of the Second World War, and second, in the "loss of internal consensus due to the withdrawal of support by certain components of the authoritarian coalition and the re-emergence of social and political opposition." ${ }^{14}$ In Albania, a special case, the fall of the totalitarian communist dictatorship ushered in a complex transformation, over the course of successive controversial elections, of the country's democratic society and political system.

Three of the political changes examined occurred in the context of an economic crisis (Indonesia, Italy, and Spain), while in the case of Albania, Indonesia, and Spain, the similarity lies in the catalyst for change (student riots). Hence, the transition processes of Indonesia and Spain involve the same two domestic variables (economic crisis and student riots), within the space of thirty years. Another reading of these contexts reveals the presence of forces from below (civic society) clamoring for educational, social and political change, while Albania, though "on the eve of democratic change," nevertheless remained "the poorest country in Europe, with no economy and little infrastructure."15 


\section{The Late and Incomplete Transition to Democracy in Albania}

The complicated transition of Albania to democracy after forty-five years of communist rule was propelled by the student movement of 1990. This transition is set apart from the other three by several factors, including the persistence of the legacy of the communist regime after the transition; the failure of the reformers to establish a truly democratic government; the ensuing political instability; and the absence of a previous democratic model. As Susan Baker and Petr Jehlička state, "The democratic character of Albania ... [has] few democratic credentials." ${ }^{16}$ The legacy of the past permeated the process, creating a contradictory situation in which the transition towards democracy was perceived as compromised, aiming to oppose and destroy communism, while at the same time retaining communist influence. Along those lines, Najada Tafili-echoing Baker and Jehlička—argues that "Albania remains an unconsolidated democracy." ${ }^{17}$

\section{Indonesia's Military Burden during the Process of Transition}

Indonesia's transition to democracy in 1998 and 1999 offers an extraordinary example of a transition carried out under the shadow of military intervention, with the army as a potential actor with the power to veto crucial political reforms. ${ }^{18}$ According to Huntington, the weakening of military power is a key factor in the establishment of civil control. ${ }^{19}$ Over the previous decades, the country had experienced various types of democracy: parliamentary democracy (1949-1957); guided democracy (1957-1959, 1959-1965); and Pancasila democracy (1966-1998), which gradually morphed into a powerful military dictatorship. ${ }^{20}$ Although the student demonstrations and occupation of Parliament in 1998 resembled the Spanish student movement of the 1960s and 1970s, the new democratic system, born of the 1999 elections was essentially, to quote Douglas Webber, a "patrimonial democracy, in which, irrespective of the staging of regular free and fair elections, holders of (not only elected) public offices [exploited] their positions primarily for their personal rather than 'universalistic' ends." ${ }^{21}$ Furthermore, "ending the military's extensive role in politics" was one of the "eight critically important issues in order to affect fundamental political reform and ensure a successful transition to democracy" put forth by Eric Bjornlund, a senior associate of the National Democratic Institute for International Affairs and its regional director for Asia, in his statement to the United States House of Representatives Committee on International Relations Subcommittee on Asia and the Pacific, on 16 February 2000. ${ }^{22}$ 


\section{The End of Fascism and the Transition to a Consolidated Republic in Italy}

The uniqueness of Italy's transition is marked by the collapse of the fascist regime in 1943, the consequent dismantling of the state machinery and the resulting breakdown of the economic system. The fall of fascism on 25 July 1943, and the signing of the armistice by the military government led by Marshal Pietro Badoglio on 8 September 1943, would lead to the formation of the National Liberation Committee (Comitato di Liberazione Nazionale, CLN). The CLN was the face of the anti-fascist political forces who focused primarily on the partisan struggle to liberate the peninsula from National Socialism and fascism, a war they waged shoulder to shoulder with the British and American Allied forces from 1943 to 1945. Later, in the wake of the referendum (on 2 and 3 June 1946) on the form of government (monarchy or republic) and in the work of the Constituent Assembly, or Assemblea Costituente (the interim parliament in charge of preparing the new constitution) the CLN focused on the country's transition to a democratic republic and on the creation of a political order based on universal suffrage and the broadest possible parliamentary representation. Italy's transition from dictatorship to democracy culminated in the election, on 18 April 1948, of the country's first republican administration (1948-1953).

In their analysis, the authors focus on the period beginning in 1958, the year of the Italian general election for the third republican parliament, ten years after the first general election, and five years after the second. When the 1958 education program was adopted, Italy was thus in the process of consolidating its democracy, and shifting towards a "new political orientation" 23 and "new trends within the political parties." ${ }^{24}$ As a matter of fact, one of the issues of the 1958 campaign was "the perennial but important question of democracy versus communism." 25

\section{Spain's Arduous Path to Democracy from within and from below}

The nature of Spain's transition to democracy is most clearly illustrated by its modus operandi, which involved negotiations frequently characterized by tension and violence. According to Robert Fishman, Spain's transition falls into the category of those that are "led by the regime [and] met with passivity or even hostility on the part of the state institutions, such as the armed forces" although, as Fishman himself points out, a successful transition also requires "the cooperation of the democratic opposition." 26 Indeed, Spain's political transition was propelled not just by the reformist groups within the regime, but by other, contrasting forces as well, which included other political parties, and civil society. Instead of effecting a revolutionary break, the sides came to a consensus and agreed to 
mutual concessions, in what Share and Mainwaring called a "transition via transaction." ${ }^{27}$ Political transition was preceded by economic liberalization in the 1960s, and modernizing educational reforms towards the end of the same decade.

\section{Education in (Political) Transition: Intertwined Temporalities}

How did these various processes of political transition and change influence the field of education, and how is that influence reflected in textbooks? To answer this question, the authors of these articles examined legislation concerning education in specific periods of time. Each country's educational policy underwent official changes. In Albania there was the Pre-University Education Law of 1995, in Indonesia the National Education System Law of 1989, in Italy the 1958 programs, and in Spain the Education Act of 1970. In each of these cases, education regulation was undertaken before, during, and after the transitions; it was omnipresent and constantly reformulated according to shifts in political alliance.

When the project of democratization is promoted from above (that is, from the ranks of the authorities or from another position of power), governments often transform textbooks into instruments that may contribute to the process by helping to construct a new identity, and a democratic legitimacy in accordance with the official agenda. ${ }^{28}$ In such situations, textbooks are considered to be political resources, vehicles that, while contributing to the process of political socialization via political and ideological re-education, nevertheless remain within the bounds of the concept of democratic governance, ${ }^{29}$ maintaining elements of the previous era and avoiding excessive criticism of the preceding political system. Yet this characteristic is not merely a result of political resistance; it is also because profound educational reforms, by their very nature, require long periods of time to be applied and to take effect; ${ }^{30}$ we can think of this as a period of maturation allowing for the development of a didactic representation of the new reality.

The contents of textbooks evolve at an even slower rate than socioeducational and politico-educational events, not to mention purely political ones such as the reforming of education policies. There can be no doubt, as Professor Agustín Escolano pointed out in his closing address at the symposium, that schools and their material culture (that is, textbooks) move on two separate timescales, while policy making (whether for educational, social, or economic policy) moves on yet a third. This disparity occurs in all cases, independently of whether the transition was negotiated or revolutionary, or whether previous transitions had taken place in other domains such as the economic or social. 
However, in countries in which a democratizing movement already existed prior to the official movement, certain sociopolitically active groups, committed to the struggle for democracy, elaborated their own progressive textbooks, thereby giving voice to the social demand for political and social transition. In keeping with the ideals of participative democracy, these innovative textbooks allowed for more active learning and, side by side with more conventional textbooks anchored in the schemes and contents of earlier times, encouraged the coexistence of tradition and innovation.

\section{Constituent Elements of a Democratic Political System}

In their study of the problem of third wave democracies, Richard Rose and Doh Chull Shin draw attention to the fact that free elections, while necessary, are not in themselves sufficient for democratization. There is another crucial element they find missing in many third-wave democracies-what they call the "basic institutions of the modern state." ${ }^{13}$ In fact, the transition to, and the construction and consolidation of, democracy is an ongoing process that requires a reformulation of the state's relationship to institutions, spheres, and individuals. Religion, the army, civic education, immigrants, and the economy are the objects of study in the textbooks examined in the special issue. These topics raised concern in the authors regarding certain aspects of education in their countries that are intimately linked to the process of transition and to the architecture of the democratic system under construction.

\section{Islam in Post-communist Albanian Textbooks}

The image of Islam promoted by the primary and secondary education system and its representation in the national history textbooks of Albania after the fall of communism is a meaningful topic, especially given the historic background: the country's Muslim majority; the religious repression under communism; and the revival of religion and freedom of public worship after the fall of communism. The ban on religion, instituted in 1967, was not lifted until November 1990. Particularly revealing is the "politicization" of religion found in these textbooks, which can be linked, for example, to the "Arab national unification" as a consequence and a cause of the spread of Islam in the 1990s. In his article, Enis Sulstarova meticulously describes how Islam is depicted in textbooks from 1990 to 2013. These textbooks are characterized by a Eurocentric approach to religion in their accounting for reasons for individuals' conversion 
to Islam (presenting "Islamization as having been both voluntary and coerced"), and they contain factual errors, bolstering an image of Islam as "part of an outdated, backward tradition".

\section{Militaristic Discourse in Indonesian Textbooks during and after the Soeharto Era}

In Indonesia, militaristic discourse and ideology was maintained and even strengthened in textbooks during the transition, surviving the various curriculum reforms carried out until the twenty-first century, thereby evidencing the power of the armed forces and their control of education, as well as the feeble nature of democracy. In his article, Hieronymus Purwanta describes how military ideals and values are constantly present in the representation of the period of the Indonesian Independence Revolution (from 1945 to 1949) in secondary school history textbooks-a representation probably linked to the conceptualization of the Revolution as a military success and object of national pride. Significantly, no major changes were made regarding the narration of this historical event in history textbooks following the country's political transition to democracy.

\section{Impediments to the Introduction of Civic Education in Italian Textbooks}

In their research on civic education in Italy, Bianchini and Morandini, illustrate how civic education was and remains a secondary topic in the Italian school curriculum. This is revealed not only in the examination of the school curriculum since 1958, but also through the analysis of textbooks that highlight the absence of a shared model of the citizen common to all political forces. It is revealing to note that civic education, even though it was introduced already in the 1958 school curriculum, that is, ten years after the transition to democracy, was never consolidated as an academic subject of unquestioned importance. In other words, although the democratic transition had been accomplished, civic education in Italian schools did not ensue.

\section{Textbooks and Economic Transition in Spain}

In their contribution, Kira Mahamud and Yovana Hernández examine social science textbooks and reading books from the last grades of primary school, as well as educational legislation, syllabi, and other contextual sources. In an approach similar to that adopted by Purwanta in his study 
of Indonesia, Mahamud and Hernández begin their analysis in the years immediately preceding the start of the political transition, and focus on the representation of economic knowledge and culture in textbookselements that are linked to the processes of political socialization and individual and collective identity construction. In Spain the economic transition preceded the political one, just as, in the sphere of education, the transition through modernization was preceded by legislation passed in the second half of the 1960s by the Franco regime, and embodied by the Education Act (Ley General de Educación) of 1970. These politicoeducational actions were the outcome of the interplay between multiple elements, including international pressure, the human capital paradigm and education planning.

The years following the enactment of the Economic Stabilization Plan (Plan de Estabilización Económica) of 1959, and especially from 1962 onwards, saw the start of the period in which the Franco regime attempted to jumpstart the economy in accordance with its own model of economic policy. These years of unfettered industrialization resulted in economic growth, consumerism, and tourism, but also in unemployment and new social inequalities that eventually led to an economic crisis on an international scale. The authors examine to what extent, and how, this economic reality was reflected in the school textbooks of the 1960s, 1970s, and 1980s.

\section{National Immigrants in Spanish Alternative Textbooks from the Basque Country}

In Spain, from the mid-1960s, there was a visible resurgence of innovative, grassroots democratizing educational trends, which were primarily (though not exclusively) born of private initiative, ${ }^{32}$ even under the yoke of the dictatorship. This phenomenon of movement toward democracy occurred at a point prior to the political transition process, which Enrique Baloyra calls the "deterioration phase," and which he characterizes as "the loss by an incumbent government of its ability to cope with the political agenda, particularly the two concerns of political economy-security and prosperity - and other salient issues of high symbolic appeal to the public," ${ }^{\prime 3}$ where the latter is evidently a reference to education.

In this context, Ander Delgado contributes a pertinent analysis of the representation of Spanish immigrants in textbooks from the 1970s, written and published in the Basque language by groups belonging to the pedagogical reform movement and the Ikastola (Basque language school) movement. Delgado's contribution is relevant because it deals with the social impact of the internal immigration to industrializing regions of Spain that took place before and during the transition to democracy, and examines the representation of this phenomenon in textbooks produced 
by groups seeking to safeguard the Basque culture and language. It draws attention to the demand of the Basque people for the recognition and promotion of their culture and language (which many felt were being threatened by the changing social reality in Spain, in particular the disturbance caused by national migration), and emphasizes the production of innovative, Basque language textbooks under the dictatorship and in the first years of the transition to democracy. Delgado shows how different political views of coexisting heterogeneous socially active groups of the time (some of which embraced a Marxist view of society) were reflected in their textbooks and in the portrayal of internal immigration.

\section{The Contribution of Textbook Research to Sociopolitical Analysis}

This special issue aims to contribute to the study of textbooks during periods of politic change in general, and transition to democracy in particular, offering a complementary analytical perspective of these processes and a new model by which to gauge the success of each country in establishing a democratic system.

The five case studies contained in this volume enable us to interpret the character of each transition process from the perspective of the knowledge officially transmitted in the schools via textbooks. Beyond merely offering one more contribution to the history of education, these studies provide unique data for sociopolitical analysis culled from an analysis of the school texts used to educate the children during the transitions and in newly born democracies-the children who are now adults living in a democratic society.

Despite the differing origins and contexts of the transitions examined, and despite varying influential factors, such as economic instability and the modernization of education, all the textbooks examined exhibited a common tendency; we see a reluctance to change the ways in which certain essential aspects of the political backdrop to the transition are perceived and conceptualized. If we accept Rafael López-Pintor's thesis that "democracy is more likely to be established successfully and maintained when there is little social inequality," ${ }^{34}$ it could be argued that although the liberalization and democratization of education helped to attenuate social inequality and encouraged social mobility (as was the case in Spain), it did not further the preparation of the young generation for participative democracy. The articles illustrate the inconsistency and insufficiency of the knowledge transmitted to the children through textbooks during the processes of transition-knowledge which, in addition to being politically slanted, was geared to encourage a political attitude of passive observation rather than active participation. These textbooks were, in turn, to shape the country's emerging democratic identity. 
Criticism may be leveled at the role of education in endorsing a conservative version of a path towards democracy, a model which would not endanger the power of the authorities, the ruling classes, and the elites. The case of Indonesia illustrates how military influence can prevent history narration in textbooks from contributing to a transition to democracy based on comprehensive knowledge of the country's history. Albanian textbooks portray Islam "as a conservative force" that "the nationalist and progressive Albanians" must espouse for the unification and emancipation of the nation and as an "object of modernization and secularization." Italy, after years of democratic government, has yet to reformulate and consolidate the teaching of civic education in education programs and textbooks. Spain's economic liberalization and modernization of education in the 1960s and 1970s did not result in a culture of democracy education via official textbooks. In all these cases, textbooks emerge as elements reflecting the active yet unhurried nature of the transitional process as objects of an educational culture characterized by the slow absorption of gradual sociopolitical changes, coexisting with a few innovative books produced and purchased by small groups of people actively involved in the transition. Could this, in addition to evidencing the authorities' stance, be a sign of political indecisiveness and instability, reflecting a lack of conviction in the knowledge imparted during the transitions?

At the same time, it is important to keep in mind that political education is, as Harold Entwistle reminds us, particularly difficult to impart successfully, since, like any other subject, it requires the "[assimilation of] attitudes and knowledge ... often running counter to the child's experiences." ${ }^{\prime 35}$ We teach our children to be honest people in a context of corrupt rulers. Here, contextual inference must be taken into account. To what extent is a given textbook's (re)presentation of the selected topics in sync with the reality of its context of production? Is the lack of a democratic foundation and orientation in the treatment of certain themes a result of the impossibility of teaching what does not yet exist? In several of the countries examined, and particularly in Spain, the process of political socialization toward democracy took place within an authoritarian context; the textbooks were created within this contradictory, political-educational framework. Is it possible for a textbook to educate students about political transition, while at the same time paving the way for an as yet non-existent democratic way of thinking and acting? Are textbooks not by nature both descriptive and prescriptive?

The adoption, by fledgling democracies, of textbooks as political and educational instruments to describe transformations and present a new form of government was followed by the introduction of similar textbooks during the first years of the new system-a development which, however, did not help prepare students for participative democracy. 
There is always a certain resistance to creating clearly pro-democracy textbooks that openly and vigorously condemn the previous authoritarian regime, incorporating consensus and dissent while encouraging an active, critical use of the text in order to foster interpretive thinking. Yet once the process of transition is over, the difference between the point of departure and the point of arrival must be clear, theoretically and empirically. Political transitions cause textbooks to experience their own slow transition or transformation of knowledge and didactics, proving that democratization is "a long term process that can usefully be thought as a chain of big and small events, not always moving unidirectionally towards full democracy." ${ }^{\prime 36}$

In addition, by addressing the question of temporality, textbooks offer an example of cultural and political educational objects that exist within the

width and thickness of time," - a width that "enables historical fluidity, conceiving the present not as a 'period' but as a process of transformation of the past into the future (and vice versa). A thickness that makes us live, simultaneously, different temporalities overlapping in such way that time is no longer a single 'thread' (the thread of time) but is represented with a string in which lots of threads are intertwined. ${ }^{37}$

Although the four countries shared the idea of a new democratic identity as an objective, necessity, and obligation, in the textbooks studied national traditions and specificities predominate over the common aim. Hence, the conceptual question of what we mean by the term "democracy" (and how we apply that meaning empirically) seems to remain at a national level: what kind of democracy do we construct in the minds of the young generation in our country, and how may we approach this objective through textbooks? Certainly, tradition, culture, and the national context condition the transition process and its outcome, but could not textbooks overcome national myopia and work towards greater ideals? Is it because no consensus exists regarding a clear definition of the concept, or because it has not been fully implemented, having reached only a state of "partial democracy"38 or "incomplete democracy" ${ }^{\prime 39}$ ), that it cannot be pedagogically processed, and theoretically and didactically portrayed in textbooks? Or do textbooks testify to a political inability to reach a national consensus on education and a minimum level of agreement among political forces, and an incapacity to reach an international agreement about political educational projects designed to ensure the construction and preservation of democratic regimes? 


\section{Notes}

1. Susan Baker and Petr Jehlička, "Dilemmas of Transition: The Environment, Democracy and Economic Reform in East Central Europe-an Introduction," Environmental Politics 7, no. 1 (1998): 3.

2. Pinar Arçali and Cennet Engin-Demir, eds., Politics, Identity and Education in Central Asia. Post-Soviet Kyrgyzstan (London and New York: Routledge, 2013), 223.

3. Anna Ascenzi, from the University of Macerata; Ana Badanelli, from the Spanish National University of Distance Education (UNED); Alberto Barausse, from the University of Molise, Paolo Bianchini, from the University of Torino; Bento Cavadas, from the Institute of Education of the Universidade Lusófona; Dorena Caroli, from the University of Macerata; Agustín Escolano, from the International Centre of School Culture (Centro Internacional de la Cultura Escolar, CEINCE); Virginia Guichot, from the University of Sevilla; Lucia Halder, from the Georg Eckert Institute for International Textbook Research; Yovana Hernández, from UNED; Justino Magalhães, from the Institute of Education of the University of Lisboa; Kira Mahamud, from UNED; Maria João Mogarro, from the Institute of Education of the University of Lisboa; Maria Cristina Morandini, from the University of Torino; Gabriela Ossenbach, from UNED; Elisabetta Patrizi, from the University of Macerata; Joaquim Pintassilgo, from the Institute of Education of the University of Lisboa; Roberto Sani, from the University of Macerata; and Miguel Somoza, from UNED.

4. A full account of the symposium is offered by Anna Ascenzi, Kira Mahamud, and Elisabetta Patrizi, "Two Recent International Events on Textbook Research. The Symposium 'Education in Periods of Political Transition' and the Workshop 'After the War. A New Beginning?'" Rassegne critiche, Discussioni, Recensioni e Bibliografia (History of Education and Children's Literature) XI, 2 (2016: 573-587.).

5. See Samuel Huntington, The Third Wave. Democratisation in the Twentieth Century, Norman: University of Oklahoma Press, 1991.

6. Enrique Baloyra, "Democratic Transition in Comparative Perspective," in Comparing New Democracies. Transition and Consolidation in Mediterranean Europe and the Southern Cone, ed. Enrique Baloyra (Boulder and London: Westview Press, 1987), 10.

7. Daniel Ziblatt, "How Did Europe Democratize?", World Politics, 58, no. 2 (2006): 333 (Review)

8. Giovanni Capoccia and Daniel Ziblatt, Introduction: "The Historical Turn in Democratization Studies: A New Research Agenda for Europe and Beyond," Comparative Political Studies 43, 8/9 (2010): 931-968.

9. Julio Samuel Valenzuela 1990, "Democratic Consolidation in Posttransitional Settings: Notion, Process, and Facilitating Conditions," working paper series, 150.

10. Giovanni Capoccia and Daniel Ziblatt, "The Historical Turn in Democratization Studies: A New Research Agenda for Europe and Beyond," Comparative Political Studies 43, 8/9 (2010): 946. 
11. Juan José Linz Storch de Gracia, "Transiciones a la Democracia," Revista Española de Estudios Sociológicos 51 (1990): 9.

12. Ashok Swain, Ramses Amer and Joakim Öjendal, eds. The Democratization Project: Opportunities and Challenges (London: Anthem Press, 2011), 4.

13. Linz, "Transiciones a la Democracia," 17.

14. Gianfranco Pasquino, "La Experiencia Italiana: Dos Transiciones (19431948; 1989-2001)," POST Data 8 (2002): 199.

15. Najada Tafili, "Consolidation of Democracy: Albania," Journal of Political Inquiry l (2008), http://politics.as.nyu.edu/object/ma_journal_issuel.html.

16. Susan Baker and Petr Jehlička, "Dilemmas of Transition. The Environment, Democracy and Economic Reform in East Central Europe-an Introduction," Environmental Politics 7, no. 1 (1998): 2.

17. Tafili, "Consolidation of Democracy: Albania," 13, http://politics.as.nyu.edu/ object/ma_journal_issuel.html.

18. According to Scott Mainwaring, the military and the capitalist class were the two groups with this power. Marcus Mietzner, "Veto Player No More? The Declining Political Influence of the Military in Postauthoritarian Indonesia," in Democracy and Islam in Indonesia, Mirjam Künkler and Alfred Stepan, eds. (New York: Columbia University Press, 2013), 90.

19. Samuel Huntington, The Soldier and the State: The Theory and Politics of Civilmilitary Relations (Cambridge and London: The Belknap Press of Harvard University Press, 1957), 80.

20. Ikrar Bhakti, "The Transition to Democracy in Indonesia: Some Outstanding Problems", in The Asia-Pacific: A Region in Transition, Jim Rolfe, ed. (Honolulu: the Asia-Pacific Center for Security Studies Published, 2004), 96-197.

21. Douglas Webber, "A Consolidated Patrimonial Democracy? Democratization in Post-Suharto Indonesia" (paper presented at the workshop, "Post Cold War Democratization in the Muslim World: Domestic, Regional and Global Trends," Granada, 14-19 April 2005, 2).

22. Eric Bjornlund, "Supporting the Democratic Transition Process in Indonesia," National Democratic Institute for International Affairs, https://www.ndi. org/files/216_id_transition.htm\#challenges.

23. Jane Perry Clark Carey and Andrew Galbraith Carey, "The Italian Elections of 1958-Unstable Stability in an Unstable World," Political Science Quarterly 73, no. 4 (1958): 566.

24. Carey and Carey, "The Italian Elections of 1958," 566.

25. Ibid., 571.

26. Robert Fishman, "Rethinking State and Regime: Southern Europe's Transition to Democracy," World Politics 42, no. 3 (1990): 422-440. Quoted in Linz, "Transiciones," 17.

27. Donald Share and Scott Mainwaring, "Transiciones Vía Transacción: La Democratización en Brasil y en España," Revista de Estudios Políticos 49 (1986): 87-135.

28. We adopt the concept of legitimacy expressed by José Ramón Montero and Leonardo Morlino in "Legitimidad y Democracia en el Sur de Europa," Revista Española de Estudios Sociológicos REIS 64 (1993): 9. Montero and Morlino define this concept, which has been endorsed by numerous other 
scholars as "a set of positive attitudes in a society towards its democratic institutions, with democracy being considered to be the most appropriate form of government." Our adoption of Montero and Morlino's definition rests on our conviction that the development and dissemination of a vision, of a positive collective imagination and of a positive attitude toward democracy is essential to the development of a sense of civic belonging, security and loyalty.

29. For a thorough study on the difference between the way in which democracy was conceptualized by the Franco regime and the various Spanish teachers' movements (a study that highlights how "both used the term 'democracy' with distinct, contradictory, and sometimes overlapping meanings)," see Tamar Groves and Cecilia Milito Barone, "Imagining a Democratic Future, Forgetting a Worrisome Past: Educational Policy, School Textbooks, and Teachers under the Franco Regime," War $\theta$ Society 33, no. 1 (2014): 43-58.

30. Manuel de Puelles Benítez, Política educativa en perspectiva histórica, Textos escogidos (Madrid: Biblioteca Nueva, 2017), 355 (forthcoming).

31. Richard Rose and Doh Chull Shin, "Democratization Backwards: The Problem of Third Wave Democracies," British Journal of Political Science, 31, no. 2 (2001): 332.

32. See Tamar Groves, Teachers and the Struggle for Democracy, 1970-1985 (London: Palgrave Macmillan, 2014), and Francisco Javier Pericacho Gómez, “Past and Present of the Pedagogic Renewal (from the Late Nineteenth Century to the Present Day). A Tour through Flagship Schools," Revista Complutense de Educación 25, no. 1 (2014): 47-67.

33. Baloyra, "Democratic Transition," 10.

34. Rafael López-Pintor, "Mass and Elite Perspectives in the Process of Transition to Democracy," Comparing New Democracies, 84.

35. Harold Entwistle, Political Education in a Democracy (London and New York: Routledge, 2012 [1971]), 22.

36. Capoccia and Ziblatt, Introduction: "The Historical Turn in Democratization Studies: A New Research Agenda for Europe and Beyond," 941.

37. António Nóvoa, Luís Miguel Carvalho, António Carlos Correia, Ana Isabel Madeira and Jorge Ramos do Ó, Flows of Educational Knowledge. The Space-Time of Portuguese Speaking Countries, in Internationalisation: Comparing Educational Systems and Semantics, Marcelo Caruso, Heinz-Elmar Tenorth, eds. (Frankfurt am Main: Peter Lang, 2002), 7-8.

38. David Epstein, Robert Bates, Jack Goldstone, Ida Kristensen and Sharyn O'Halloran, "Democratic Transitions," American Journal of Political Science 50, no. 3 (2006): 551.

39. Rose and Shin, "Democratization Backwards," 331. 